\title{
Making it normal to sell death: two books worth reading
}

\author{
Ruth E Malone
}

During the Christmas and New Year holidays, a long vacation finally allowed me the time and opportunity to read two of last year's blockbuster books on tobacco control: Robert Proctor's Golden Holocaust: Origins of the cigarette catastrophe and the case for abolition ${ }^{1}$ and Sharon Eubanks and Stanton Glantz's Bad acts: The racketeering case against the tobacco industry. ${ }^{2}$ Full disclosure: I wrote a cover note for Proctor's book after seeing drafts of some chapters; I also served as a consultant to the US Department of Justice in US Department of Justice versus Philip Morris et al, the landmark legal case that is the subject of the second book. Taken together, these books pointed to some things tobacco control practitioners, researchers, and advocates, whatever their disciplinary field or focus, should be reminded of frequently.

First, individual acts do matter. In public health and tobacco control, the problems sometimes seem so pervasive and systemic that we can't imagine how things will ever change. But with persistence and determination, they do. In Golden Holocaust, we see the grim evidence of how decisions made over the last halfcentury by individuals working for the tobacco industry shaped an epidemic - an epidemic that didn't have to happen, but for the tobacco industry's single-minded focus on sustaining its profits, at all costs. These were decisions made by individuals and groups of individuals who colluded together within and even across competitive company boundaries to deceive the public and policymakers about the effects of their products on human beings. They carefully put pieces together to construct an elaborate fiction. They made it seem normal to sell death.

Correspondence to Professor Ruth E Malone, Department of Social and Behavioral Sciences, University of California, San Francisco, CA 94118, USA; ruth.malone@ucsf.edu
Holocaust comparisons are overused and run the risk of trivialising the original holocaust. But in this case, the sheer numbers, the extent and elaborateness of the deceptions deployed, and the continued willful ignorance (or corruption) of governments really do call for strong language to convey what has transpired and continues to transpire. During the last century, tobacco killed 100 million people - the vast majority of whom were users of commercially manufactured cigarettes, which we now know (as Proctor's book details) were engineered in ways that enhanced both their addictiveness and their likelihood of causing disease. What other consumer product, heavily marketed, would be tolerated by governments if it did that?

Proctor's book adds to the mountain of evidence from tobacco company internal documents that have changed the legal landscape of tobacco control-the subject of the second book. In Bad Acts, we see how those documents were skillfully deployed in a federal courtroom. But we also see how ambivalent or outright hostile a government can be about reining in this industry - in this case, the George W Bush administration clearly wanted to 'disappear' the case, so as not to upset major corporate and individual donors to Republican causes. Yet a very small band of US Department of Justice lawyers used their legal and organisational savvy, their connections, incredibly hard work, and sheer gutsiness to win an enormous racketeering case against the major tobacco companies and their organisations - a case that, in the beginning, almost no one thought they could win.

This book helps remind us that doing the right thing matters, even when it comes at a cost. At numerous points in Bad Acts, the Department of Justice tobacco team was pressured to back off the case, but withstood or countered the pressure and continued to fight. Anonymous individuals helped them behind the scenes, sharing information with the media and helping them sidestep pitfalls. It is a fascinating read, and after the first few chapters (which could have used a bit of judicious editing), becomes a pageturner.

I remember sitting in the courtroom watching that trial in Washington, DC. There was a veritable army of tobacco industry lawyers on the left side of the room, and on the other side a small band of very young-looking Department of Justice lawyers. For once I was unabashedly proud of how my tax dollars were being spent. It was hard to imagine how that little band could keep up with the other side, much less prevail. But prevail they did. And in November, 2012, after having apparently exhausted their appeals, the tobacco companies were ordered by the judge to publish advertisements admitting they lied to and deceived the public. Among the statements the companies must include in advertisements: 'Defendant tobacco companies intentionally designed cigarettes to make them more addictive' ${ }^{3}$

Will admitting they lied lead us out of the 20th century tobacco holocaust to the tobacco endgame we are beginning to envision? Not alone. But it is part of deconstructing the normalcy of selling death in pretty packages. When those ads appear, tobacco control advocates all over the world should make sure they get lots of attention. It's the least we can do to honour the memories of the 100 million dead.

\section{Competing interests None.}

Provenance and peer review Commissioned; internally peer reviewed.

Tobacco Control 2013;22:65.

doi:10.1136/tobaccocontrol-2013-050984

\section{REFERENCES}

1. Proctor R. Golden holocaust: origins of the cigarette catastrophe and the case for abolition. Berkeley, CA: University of California Press, 2012.

2. Eubanks S, Glantz SA. Bad acts: the racketeering case against the tobacco industry. Washington, DC: American Public Health Association, 2012.

3. Associated Press. Judge orders tobacco companies to say they lied. USA Today online:http:// www.usatoday.com/story/news/nation/2012/11/27/ judge-smoking-cigarettes-tobacco-lied/1730305/ (accessed 19 Jan 2013). 